\title{
POSACONAZOLE TREATMENT OF REFRACTORY EUMYCETOMA AND CHROMOBLASTOMYCOSIS
}

\author{
Ricardo NEGRONI(1), Angela TOBÓn(2), Beatriz BUSTAMANTE(3), Maria Aparecida SHIKANAI-YASUDA(4), Hernando PATINO(5) \& Angela RESTREPO(2)
}

\begin{abstract}
SUMMARY
Eumycetoma and chromoblastomycosis are chronic, disfiguring fungal infections of the subcutaneous tissue that rarely resolve spontaneously. Most patients do not achieve sustained long-term benefits from available treatments; therefore, new therapeutic options are needed. We evaluated the efficacy of posaconazole, a new extended-spectrum triazole antifungal agent, in 12 patients with eumycetoma or chromoblastomycosis refractory to existing antifungal therapies.

Posaconazole $800 \mathrm{mg} / \mathrm{d}$ was given in divided doses for a maximum of 34 months. Complete or partial clinical response was considered a success; stable disease or failure was considered a nonsuccess.

All 12 patients had proven infections refractory to standard therapy. Clinical success was reported for five of six patients with eumycetoma and five of six patients with chromoblastomycosis. Two patients were reported to have stable disease. As part of a treatment-use extension protocol, two patients with eumycetoma who initially had successful outcome were successfully retreated with posaconazole after a treatment hiatus of $>10$ months. Posaconazole was well tolerated during long-term administration (up to $1015 \mathrm{~d})$.

Posaconazole therapy resulted in successful outcome in most patients with eumycetoma or chromoblastomycosis refractory to standard therapies, suggesting that posaconazole may be an important treatment option for these diseases.
\end{abstract}

KEYWORDS: Posaconazole; Eumycetoma; Chromoblastomycosis; Refractory.

\section{INTRODUCTION}

Eumycetoma and chromoblastomycosis are chronic fungal infections involving cutaneous and subcutaneous tissues caused by direct inoculation through the $\operatorname{skin}^{1,2,5,10,17,23,32,35,36,53,57}$. In the case of eumycetoma, other tissues are also attacked, including bones and joints ${ }^{19,27}$. Although both mycoses present a widespread geographical distribution, they are most common in tropical countries ${ }^{7,9,35,36}$.

Posaconazole is a new, extended-spectrum triazole antifungal agent that has demonstrated in vitro activity against many of the fungal pathogens that cause eumycetoma and chromoblastomycosis, including S. apiospermum ${ }^{14,33,43,49}$, P. boydii ${ }^{16,20,43,52}$, and Fonsecaea spp. Additionally, it has demonstrated clinical activity against filamentous and other fungi, including those resistant to amphotericin B and/or itraconazole, suggesting it may provide broad clinical usefulness in the treatment of fungal infections ${ }^{24,34,51}$. Furthermore, posaconazole has demonstrated in vivo activity against $P$. boydii ${ }^{20}$ and $S$. apiospermum ${ }^{34}$.

We report on the efficacy and safety of posaconazole in the treatment of 12 patients with eumycetoma or chromoblastomycosis. These patients were part of a large, multinational, open-label study conducted to assess the safety and efficacy of posaconazole in patients $(\mathrm{N}=330)$ with invasive fungal infections who were intolerant of, or who had disease refractory to conventional antifungal medications.

\section{MATERIALS AND METHODS}

Patients: Patients at least 13 years of age of any gender or race, with proven, probable, or possible invasive fungal infection ${ }^{6}$ who were able to swallow an oral suspension and comply with the treatment regimen were eligible for study participation. Patients had to be intolerant to, or have disease refractory to, standard antifungal therapy. Patients were considered intolerant to standard therapies if they experienced organ toxicity, had preexisting renal insufficiency, or experienced idiosyncratic or major anaphylactic reactions to other antifungal agents. For the purpose of this study, patients at high risk for toxicity by virtue of their underlying disease or concomitant medications also were considered intolerant to standard therapies. Patients were considered to have refractory disease if their disease progressed or if they failed to improve clinically, despite extended or repetitive courses of antifungal therapy.

In accordance with the Declaration of Helsinki, written informed

(1) Hospital F.J. Muñiz, Buenos Aires, Argentina.

(2) Corporación para Investigaciones Biológicas, Medellín, Colombia.

(3) Hospital Nacional Cayetano Heredia, Lima, Peru.

(4) Hospital das Clinicas da FMUSP, São Paulo, SP, Brasil.

(5) Schering-Plough Research Institute, Kenilworth, NJ, USA.

This paper was presented, in part, at the 43rd Annual Interscience Conference on Antimicrobial Agents and Chemotherapy; September 14-17, 2003, Chicago, IL.

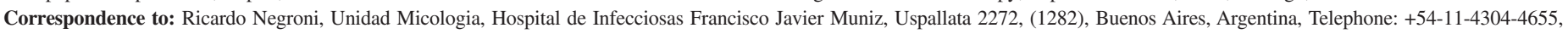

Fax: + 54-11-4304-4655. hmmicologia@intramed.net.ar 


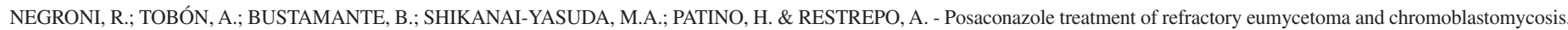
Rev. Inst. Med. trop. S. Paulo, 47(6):339-346, 2005.

consent and approval by an accredited institutional review board were obtained prior to initiation of any study-related activities.

Study design: In this open-label, multicenter clinical study, all patients were treated with posaconazole (Schering Plough, Kenilworth, NJ, USA) $800 \mathrm{mg}$ daily given orally in divided doses (400 mg two times daily or $200 \mathrm{mg}$ four times daily). Patients were monitored at weeks 1,2 , and 4 , every month thereafter, at the end of treatment, and for 30 days posttherapy. The protocol-defined treatment duration was a maximum of 12 months; however, patients who required longer therapy were eligible for enrollment in a separate treatment-use extension protocol.

Clinical response: Clinical response to therapy was evaluated at weeks 2 and 4, then monthly, and at the end of therapy. Treatment was considered a success if a patient experienced a total resolution (complete response) or improvement (partial response) in all attributable symptoms, signs, and radiographic abnormalities, if present at enrollment. Treatment was considered a nonsuccess if there was no improvement in attributable symptoms, signs, and radiographic abnormalities, if present at enrollment (stable disease), or if there was deterioration in attributable clinical or radiographic abnormalities necessitating alternative antifungal therapy or resulting in death (failure).

Safety assessments: Safety and tolerability were evaluated throughout the study period. Adverse events were recorded and categorized using the National Institute of Allergy and Infectious Diseases (NIAID) AIDS grading system, when possible. When adverse events did not fall into the NIAID categories, an alternative grading system was used whereby adverse events were scored as mild, moderate, severe, or life threatening. The relationship of each adverse effect to posaconazole therapy (unlikely, possible, or probably) and whether the effect necessitated premature discontinuation of therapy or hospitalization was also assessed. Blood samples were collected at each visit during treatment and at the final posttherapy visit for routine hematologic and chemistry evaluations. In addition, a standard 12-lead electrocardiogram was obtained at the baseline visit and at week 4 .

\section{RESULTS}

Eleven patients had proven chromoblastomycosis or eumycetoma as determined by fungal cultures and one patient was diagnosed with eumycetoma by histopathology. All patients had disease considered to be refractory to standard therapies, but none were considered to be intolerant. Most patients (11 of 12) were men with a mean age of 47 years. Six of the patients had eumycetoma; five were caused by Madurella spp., and one was caused by $S$. apiospermum. Six patients had chromoblastomycosis, all caused by $F$. pedrosoi. All patients had a long disease history (range: 3 - 29 years). Sites of infection primarily involved the skin and soft tissues of the lower extremities (foot and leg); bone involvement was observed in five of six patients with eumycetoma. Prior antifungal therapy consisted of ketoconazole and itraconazole for patients with eumycetoma (total cumulative duration: 2 mo to $\sim 27 \mathrm{mo}$ ) and terbinafine, itraconazole, and flucytosine for patients with chromoblastomycosis (total cumulative duration: $17 \mathrm{mo}$ to $\sim 8$ y). Baseline patient characteristics are shown in Table 1.

Clinical success was achieved by five of six patients (four with complete response, one with partial) with eumycetoma and by five of six patients (four with complete response, one with partial) with chromoblastomycosis. Overall, significant clinical improvement was observed in nine patients during the first six months of posaconazole therapy. At the end of treatment, negative fungal cultures were observed in four patients with eumycetoma and in four patients with chromoblastomycosis.

Of the two patients who were considered a nonsuccess (one with eumycetoma; one with chromoblastomycosis) both had stable disease at the end of posaconazole therapy. In patient 10 , posaconazole therapy halted the progression of chromoblastomycosis and resulted in some

Table 1

Patient demographics, etiologic and clinical characteristics

Patient Age Sex Disease Organism Site of infection (tissue involved)
(includes relapses and remissions)

\begin{tabular}{|c|c|c|c|c|c|c|}
\hline $1 *$ & 35 & M & Eumycetoma & M. grisea & Foot, knee, leg (skin/subcutaneous tissue, bone) & 13 \\
\hline $2 * \dagger$ & 40 & M & Eumycetoma & M. grisea & Foot, ankle (skin/subcutaneous tissue) & 20 \\
\hline 3 & 38 & M & Eumycetoma & M. grisea & Foot, ankle (skin/subcutaneous tissue, bone) & 7 \\
\hline $4^{* \dagger}$ & 25 & $\mathrm{M}$ & Eumycetoma & S. apiospermum & Foot (skin/subcutaneous tissue, bone) & 14 \\
\hline 5 & 37 & M & Eumycetoma & M. mycetomatis & Foot (skin/subcutaneous tissue, bone) & 23 \\
\hline 6 & 50 & M & Eumycetoma & M. mycetomatis & Foot (skin/subcutaneous tissue, bone) & 4 \\
\hline 7 & 45 & $\mathrm{~F}$ & Chromoblastomycosis & F. pedrosoi & Buttock (skin/subcutaneous tissue) & 12 \\
\hline 8 & 69 & M & Chromoblastomycosis & F. pedrosoi & Leg (skin/subcutaneous tissue) & 4 \\
\hline 9 & 55 & M & Chromoblastomycosis & F. pedrosoi & Leg (skin/subcutaneous tissue) & 3 \\
\hline $10^{*}$ & 47 & M & Chromoblastomycosis & F. pedrosoi & Legs, arm (skin/subcutaneous tissue) & 16 \\
\hline 11 & 69 & M & Chromoblastomycosis & F. pedrosoi & Leg (skin/subcutaneous tissue) & 29 \\
\hline 12 & 53 & M & Chromoblastomycosis & F. pedrosoi & Leg (skin/subcutaneous tissue) & 8 \\
\hline
\end{tabular}

*Patients received a second course of posaconazole therapy as part of a treatment-use extension protocol; ${ }^{\dagger}$ Second course of posaconazole therapy was given after a 10 to 12 -month treatment hiatus. 
symptomatic improvement. During the fourth month of posaconazole therapy, the chromoblastomycosis worsened; a medical examination revealed the patient had diabetes mellitus. Management of the diabetes was associated with lesion improvement and decreased pain that resulted in increased mobility and the ability to perform daily chores. Cultures remained positive for $F$. pedrosoi at the end of treatment. After an additional 11 months of posaconazole therapy (as part of a treatmentuse extension protocol), the patient's disease relapsed and therapy was discontinued. Diabetes was well controlled at the time of relapse. Clinical summaries of all patients are provided in Table 2 and Table 3.

Patient 2 and patient 4, both of whom had a successful outcome, had a relapse of eumycetoma after a 10- to 12-month treatment hiatus. Both patients received a second course of posaconazole therapy as part of a treatment-use extension protocol. Successful outcomes were observed in both patients after the second course of posaconazole therapy (Table 2). Currently, all lesions on patient 4 have disappeared, and although osteomyelitis is still apparent on radiologic images of the foot, he remains in good health.

Posaconazole was generally well tolerated by these 12 patients with eumycetoma and chromoblastomycosis. Treatment-related adverse events were headache $(n=2)$ and elevated bilirubin levels $(n=2)$. One subject with hyperbilirubinemia had a baseline bilirubin value of 0.5 $\mathrm{mg} / \mathrm{dL}$ and elevation was observed on day 50 of therapy with a maximum value of $1.2 \mathrm{mg} / \mathrm{dL}$. No elevations of transaminases were seen in this subject and a final diagnosis of Gilbert's disease was made. The second subject with elevated bilirubin presented with elevated transaminases at baseline and had intermittent elevation of bilirubin during study. The patient's maximum bilirubin value was $1.6 \mathrm{mg} / \mathrm{dL}$. Although patient 10 developed diabetes while on posaconazole therapy, it was considered unrelated to therapy. No adverse events leading to drug discontinuation occurred in the patients with eumycetoma or chromoblastomycosis. Only one adverse event was considered serious (headache) but unrelated to posaconazole. Posaconazole was not associated with QTc prolongation or negative inotropic effects, and it did not cause visual disturbances.

Representative case: eumycetoma (patient \#2): A 40-year-old man with a 20-year history of eumycetoma caused by $M$. grisea sought treatment for nodules and fistulae on the left foot with osteolytic lesions in the thalus, calcaneal, and navicular bones (patient 2; Fig. 1a). Before study entry, several courses of itraconazole (cumulative duration, 10 mo) and ketoconazole (cumulative duration, 3 mo) therapy failed; neither produced sustained microbiology and clinical improvement. Salvage therapy with posaconazole was initiated.

Response to posaconazole therapy was first evident at month 3, at which time the patient's fistulae resolved, nodules became smaller, and pain lessened. By month 6, his ankle nodules had resolved, but there

Table 2

Summary of patients treated with posaconazole for eumycetoma considered refractory to standard therapy

\begin{tabular}{|c|c|c|c|c|c|c|c|}
\hline \multicolumn{4}{|c|}{ Prior Antifungal Therapy } & \multicolumn{4}{|c|}{ Posaconazole Therapy } \\
\hline Patient & Drug & $\begin{array}{l}\text { Dose } \\
(\mathrm{mg} / \mathrm{d})\end{array}$ & $\begin{array}{l}\text { Cumulative } \\
\text { duration (mo) }\end{array}$ & $\begin{array}{l}\text { Duration } \\
\text { (d) }\end{array}$ & $\begin{array}{l}\text { Response } \\
(6 \mathrm{mo})\end{array}$ & $\begin{array}{c}\text { Response } \\
\text { (end of treatment) }\end{array}$ & Outcome \\
\hline 1 & $\begin{array}{l}\text { KTZ } \\
\text { ITZ }\end{array}$ & $\begin{array}{l}400 \\
200\end{array}$ & $\begin{array}{l}6 \\
6\end{array}$ & 1015 & $\begin{array}{l}\text { Knee and foot nodule } \\
\text { improvement }\end{array}$ & $\begin{array}{l}\text { Negative skin fungal cultures; } \\
\text { foot nodules resolved }\end{array}$ & Success (complete) \\
\hline $\begin{array}{c}2 \\
\text { (Treatment } \\
\text { period 1) }\end{array}$ & $\begin{array}{l}\text { ITZ } \\
\text { ITZ } \\
\text { KTZ }\end{array}$ & $\begin{array}{l}200 \\
400 \\
400\end{array}$ & $\begin{array}{l}\sim 2 \\
8 \\
3\end{array}$ & 367 & $\begin{array}{l}\text { Resolution of ankle } \\
\text { nodules; slight } \\
\text { recurrence of } \\
\text { foot nodules }\end{array}$ & $\begin{array}{l}\text { Skin absent of fungal } \\
\text { elements; resolution of } \\
\text { pain, tumor, nodules; } \\
\text { negative fungal cultures }\end{array}$ & Success (complete) \\
\hline $\begin{array}{l}2 \\
\text { (Treatment } \\
\text { period } 2 *)\end{array}$ & & & & 398 & $\begin{array}{l}\text { Resolution of pain; } \\
\text { improved lesions, } \\
\text { mobility }\end{array}$ & $\begin{array}{l}\text { Negative skin fungal cultures; } \\
\text { resolution of bone } \\
\text { abnormalities, pain, } \\
\text { tumor, nodules }\end{array}$ & Success (complete) \\
\hline 3 & ITZ & 200 & $\sim 13$ & 239 & Ankle nodule was excised & Overall improvement & Success (complete) \\
\hline $\begin{array}{c}4 \\
\text { (Treatment } \\
\text { period 1) }\end{array}$ & $\begin{array}{l}\text { ITZ } \\
\text { ITZ } \\
\text { ITZ }\end{array}$ & $\begin{array}{l}200 \\
300 \\
800\end{array}$ & $\begin{array}{c}9 \\
1 \\
17\end{array}$ & 388 & $\begin{array}{l}\text { Improved signs } \\
\text { and symptoms }\end{array}$ & $\begin{array}{l}\text { Fungal cultures grew } \\
P . \text { boydii and } S . \text { apiospermum; } \\
\text { ongoing foot tumor and pain }\end{array}$ & Success (partial) \\
\hline $\begin{array}{l}4 \\
(\text { Treatment } \\
\text { period } 2 *)\end{array}$ & & & & 445 & & $\begin{array}{l}\text { Increased motility without } \\
\text { pain; skin lesions resolved; } \\
\text { evidence of osteomyelitis }\end{array}$ & Success (partial) \\
\hline 5 & KTZ & 400 & 4 & 168 & $\begin{array}{l}\text { Improved signs and } \\
\text { fungal culture; continu }\end{array}$ & $\begin{array}{l}\text { symptoms; negative skin } \\
\text { led evidence of eumycetoma }\end{array}$ & Nonsuccess (stable) \\
\hline 6 & KTZ & 800 & 2 & 252 & $\begin{array}{l}\text { No change in signs } \\
\text { and symptoms }\end{array}$ & $\begin{array}{l}\text { Negative skin fungal cultures/ } \\
\text { histology of nodule biopsy; } \\
\text { normal radiology }\end{array}$ & Success (complete) \\
\hline
\end{tabular}

*Treatment extension period; ITZ = itraconazole; KTZ = ketoconazole. 


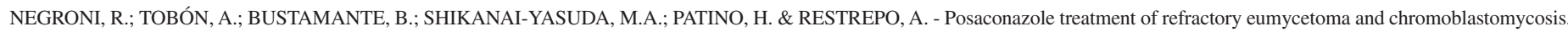
Rev. Inst. Med. trop. S. Paulo, 47(6):339-346, 2005.

Table 3

Summary of patients treated with posaconazole for chromoblastomycosis considered refractory to standard therapy

\begin{tabular}{|c|c|c|c|c|c|c|c|}
\hline \multicolumn{4}{|c|}{ Prior Antifungal Therapy } & \multicolumn{4}{|c|}{ Posaconazole Therapy } \\
\hline Patient & Drug & $\begin{array}{l}\text { Dose } \\
(\mathrm{mg} / \mathrm{d})\end{array}$ & $\begin{array}{l}\text { Cumulative } \\
\text { duration (mo) }\end{array}$ & $\begin{array}{l}\text { Duration } \\
\text { (d) }\end{array}$ & $\begin{array}{l}\text { Response } \\
(6 \mathrm{mo})\end{array}$ & $\begin{array}{c}\text { Response } \\
\text { (end of treatment) }\end{array}$ & Outcome \\
\hline 7 & $\begin{array}{l}\text { TRB } \\
\text { ITZ }\end{array}$ & $\begin{array}{l}500 \\
400\end{array}$ & $\begin{array}{l}12 \\
24\end{array}$ & 376 & $\begin{array}{l}\text { Skin lesion } \\
\text { improvement }\end{array}$ & $\begin{array}{c}\text { Skin lesion resolved; } \\
\text { negative skin fungal culture }\end{array}$ & Success (complete) \\
\hline 8 & $\begin{array}{l}\text { ITZ } \\
\text { TRB } \\
\text { ITZ }\end{array}$ & $\begin{array}{l}200 \\
250 \\
300\end{array}$ & $\begin{array}{c}10 \\
2 \\
5\end{array}$ & 268 & $\begin{array}{l}\text { Leg nodule } \\
\text { improvement }\end{array}$ & Ongoing mild nodules & Success (partial) \\
\hline 9 & $\begin{array}{l}\text { ITZ } \\
\text { TRB }\end{array}$ & $\begin{array}{c}200 \\
1000\end{array}$ & $\begin{array}{c}6 \\
16\end{array}$ & 174 & Ulcer resolved; & egative fungal culture & Success (complete) \\
\hline $\begin{array}{l}10 \\
\text { (Treatment } \\
\text { period 1) }\end{array}$ & $\begin{array}{l}\text { ITZ } \\
\text { FC } \\
\text { TRB } \\
\text { SAP }\end{array}$ & $\begin{array}{c}100-300 \\
1000 \\
1000 \\
200\end{array}$ & $\begin{array}{c}\sim 62 \\
8 \\
12 \\
18\end{array}$ & 375 & $\begin{array}{l}\text { Lesions and pain } \\
\text { persisted; skin cultures } \\
\text { positive for } F \text {. pedrosoi }\end{array}$ & $\begin{array}{l}\text { Lesion improvement; } \\
\text { skin cultures positive } \\
\text { for } F \text {. pedrosoi }\end{array}$ & Nonsuccess (stable) \\
\hline $\begin{array}{c}10 \\
\text { (Treatment } \\
\text { period } 2 *)\end{array}$ & & & & 293 & $\begin{array}{l}\text { Symptomatic } \\
\text { improvement; } \\
\text { skin cultures positive } \\
\text { for } F \text {. pedrosoi }\end{array}$ & $\begin{array}{l}\text { Symptomatic improvements } \\
\text { for } 11 \text { mo; cultures } \\
\text { remained positive; disease } \\
\text { worsened, POS discontinued }\end{array}$ & $\begin{array}{c}\text { Nonsuccess } \\
\text { (mycosis reactivated) }\end{array}$ \\
\hline 11 & $\begin{array}{c}\text { ITZ } \\
\text { FC } \\
\text { TRB }\end{array}$ & $\begin{array}{c}200 \\
750 \\
1000\end{array}$ & $\begin{array}{l}29 \\
10 \\
12\end{array}$ & 343 & $\begin{array}{l}\text { Nodule improvement; } \\
\text { negative fungal culture }\end{array}$ & $\begin{array}{l}\text { Negative sequential } \\
\text { fungal cultures }\end{array}$ & Success (complete) \\
\hline 12 & $\begin{array}{l}\text { ITZ } \\
\text { TRB }\end{array}$ & $\begin{array}{l}200 \\
500\end{array}$ & $\begin{array}{l}58 \\
17\end{array}$ & 182 & Resolution of skin ulc & ars; negative fungal cultures & Success (complete) \\
\hline
\end{tabular}

*Treatment extension period; FC = flucytosine; ITZ = itraconazole; KTZ = ketoconazole; POS = posaconazole; $\mathrm{SAP}=$ saperconazole; TRB = terbinafine.

was a slight recurrence of his foot nodules. Biopsy samples taken of the lesion showed grains with dark hyphae, but fungal cultures were negative. At the end of treatment (month 12), the nodules, edema, and pain had resolved. Biopsy samples of the skin showed inflammation, but fungal cultures were negative. Posaconazole therapy was discontinued.

The patient had a relapse after a 12-month treatment hiatus, at which time he presented with edema, nodules, and fistulae on the left foot and ankle with associated motion-related pain. Radiographic results revealed an osteolytic lesion in the calcaneus bone and periostitis of the first metatarsal. Posaconazole therapy was restarted as part of a treatment-use extension protocol. Nodule size, pain, and edema diminished by month 2 . By month 6 , his foot pain had resolved, he had greater ankle motility, and the fistulae closed. At his 9-month visit, his left foot and ankle lesions were greatly reduced; however, a nodule in the left Achilles' tendon was noted. Surgical excision of the ankle nodule was performed after 11 months of posaconazole therapy. Histologic and mycologic examination of the nodule showed inflammation but no fungal elements. The patient tolerated posaconazole well and remains on posaconazole therapy. Recent imaging of the foot shows resolution of all bone lesions (Fig. 1b).

Representative case: chromoblastomycosis (patient \#11). A 69year-old man with a 29-year history of chromoblastomycosis caused by $F$. pedrosoi sought treatment for ulcerated nodules on his left leg (patient 11; Fig. 2a). Before study entry, several courses of standard antifungal therapy had failed, among them amphotericin B (duration of therapy unknown), itraconazole ( $>2$-y duration), flucytosine $(\sim 1-\mathrm{y}$ duration), and terbinafine (1-y duration).

Response to posaconazole therapy was evident first at month 1, at which time ulcerated nodules had improved. A culture of a skin specimen collected at this time was positive for $F$. pedrosoi. The ulcerated nodules did not change between the 1-month and 3-month visits; however, by month 6, they had improved considerably. Skin cultures were negative for $F$. pedrosoi at month 4; five additional skin cultures performed between months 5 and 10 also were negative for this fungus. Continued clinical improvement was noted at months 8 and 12 (Fig. 2b).

\section{DISCUSSION}

Because the causative fungal pathogens may prove resistant to conventional antifungal therapies, eumycetomas and chromoblastomycoses are challenging infections to manage. Many patients experience remitting and relapsing disease and suffer from disfigurement and discomfort for years. Although long-term medical therapy usually is needed to produce a sustained clinical response, tolerability and adverse events may reduce the likelihood of achieving it. As a result, clinical success rates of both pharmacologic and nonpharmacologic therapies published thus far in the literature remain unacceptably low, demonstrating the need for new therapies.

However, the assessment of therapies for these infections is difficult because of the chronic nature of the disease and the observed high 

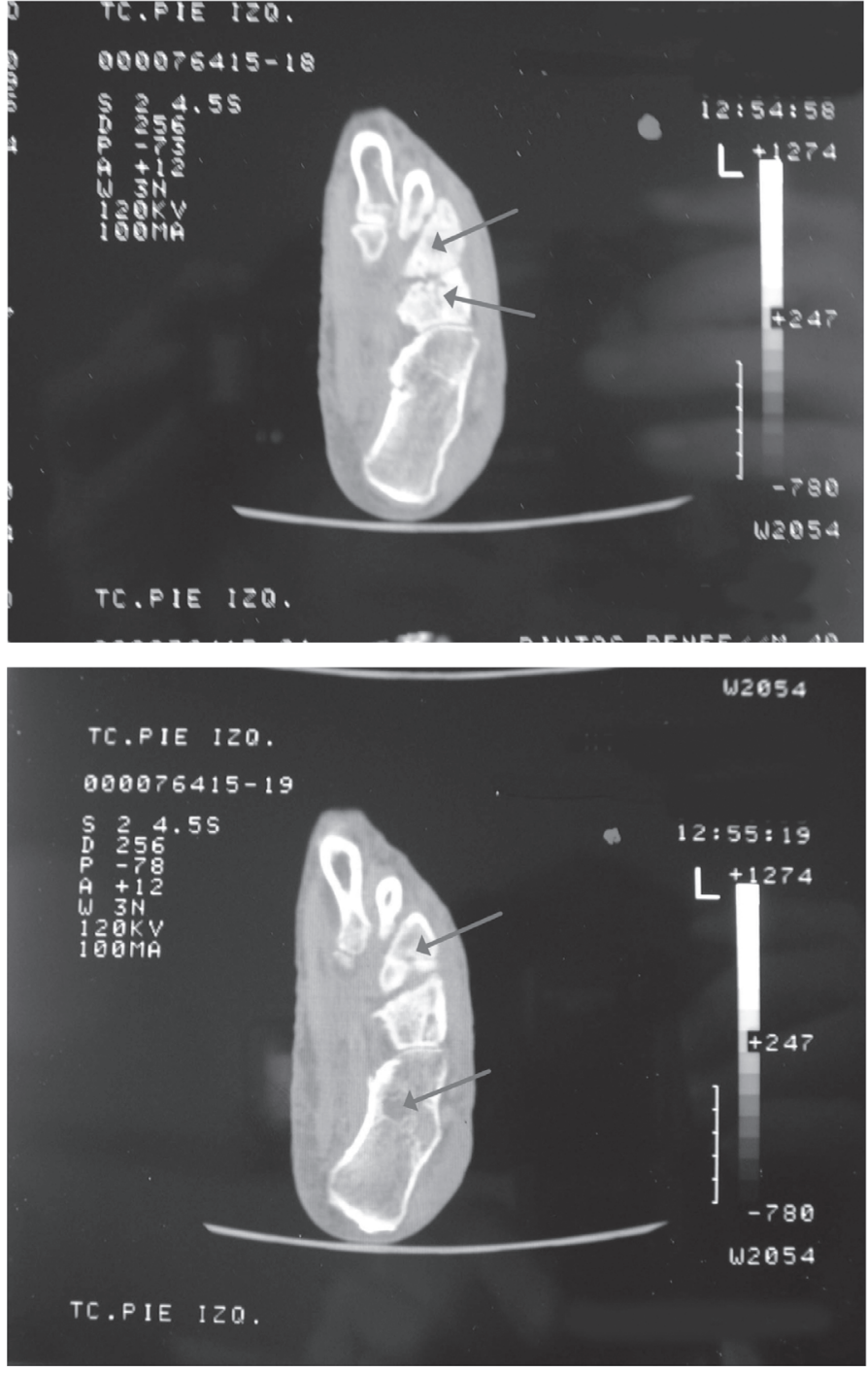

Fig. 1a - Computed tomography of the foot at presentation (treatment period 1) before posaconazole therapy. Arrows show lytic lesions in the thalus, calcaneal, and navicular bones (patient 2).

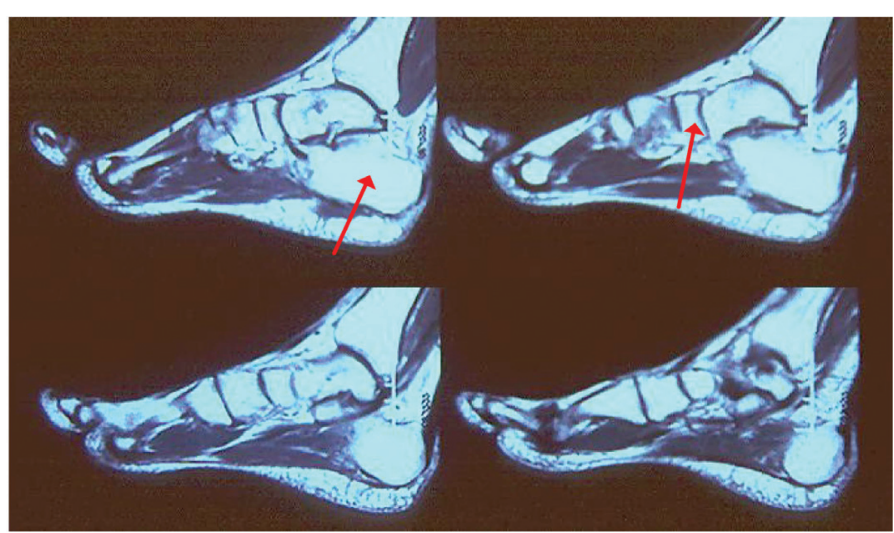

Fig. 1b - Computed tomography of the foot after the second course of posaconazole. (14 months). Arrows show complete resolution of calcaneal and navicular bone lesions (patient 2).
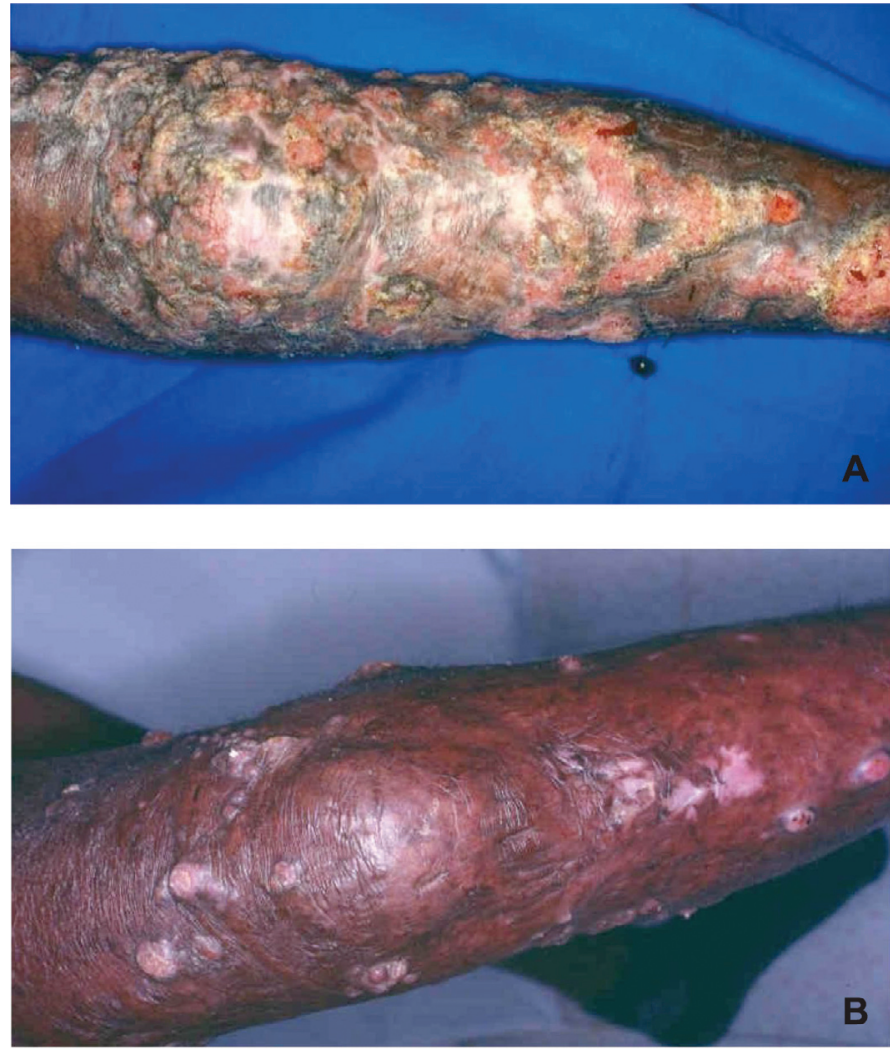

Fig. 2 - Response of chromoblastomycosis to posaconazole therapy (patient 11): A) a presentation before posaconazole treatment; B) after 12 months of posaconazole therapy.

relapse rate. For example, in the case of eumycetomas, clinical assessment includes changes in nodule diameter and the amount of purulent secretions, and the disappearance of sinus tracts. Eradication of the pathogen is difficult to prove, even when deep biopsies are performed. In our experience, we have observed relapses in several patients in whom bone biopsy cultures were negative. Additionally, clinical response varies by the causative species. Because of these circumstances, long-term follow up is required for these patients.

In the current study, posaconazole therapy produced successful clinical outcomes in five of six patients with eumycetoma and five of six patients with chromoblastomycosis considered refractory to conventional therapies. In many patients, posaconazole therapy resulted in significant clinical improvements, often within the first six months of therapy, and was well tolerated during long-term (up to $1015 \mathrm{~d}$ ) administration. Successful outcome was associated with various symptomatic improvements; lesion diameter decreased, fistula closed, secretions lessened, pain and swelling resolved, and motility increased. Resolution of bone abnormalities also were observed in patients with eumycetoma infections that caused osteomyelitis, suggesting that posaconazole may penetrate this tissue after oral administration.

Although two patients had stable disease at the end of treatment and thus were considered nonsuccesses, this outcome may be of significant clinical importance to patients who had progressive or worsening disease before posaconazole therapy. For example, patient 


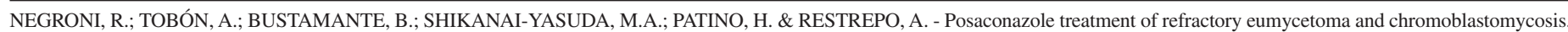
Rev. Inst. Med. trop. S. Paulo, 47(6):339-346, 2005.

10 had chromoblastomycosis that was progressing significantly prior to initiating treatment. Posaconazole therapy halted the progression and resulted in significant symptomatic improvements for most of the first year of treatment. Although this patient was considered to have stable disease at the end of therapy, the clinical improvement associated with posaconazole therapy improved patient's ability to walk and to perform daily chores. Regaining the ability to perform these activities may offer some therapeutic advantage in these challenging-to-manage chronic diseases. After completing the study, patient 10 continued to receive posaconazole therapy as part of a treatment-use extension protocol. The first few months of additional posaconazole therapy were associated with symptomatic improvement; however, after 11 months, the patient suffered a relapse and posaconazole therapy was discontinued owing to treatment failure. The failure was not thought to be due to diabetes, as this condition had been well controlled.

Although the susceptibility of the eumycetoma causing fungal pathogens to the azoles varies greatly, they often are tried because the causative organisms generally are resistant to amphotericin $\mathrm{B}^{41}$; thus, therapeutic options are limited. In susceptibility studies, reported minimum inhibitory concentration (MIC) ranges of fluconazole and itraconazole against $P$. boydii are $32 \mu \mathrm{g} / \mathrm{mL}$ to $>64 \mu \mathrm{g} / \mathrm{mL}$ and $0.5 \mu \mathrm{g} /$ $\mathrm{mL}$ to $4 \mu \mathrm{g} / \mathrm{mL}$, respectively ${ }^{20,52}$. Itraconazole MICs range from $0.25 \mu \mathrm{g} /$ $\mathrm{mL}$ to $8 \mu \mathrm{g} / \mathrm{mL}$ against $S$. apiospermum (the teleomorph of $P$. boydii) ${ }^{26,33}$. Additionally, clinical outcome following treatment with azoles is variable. Reported response rates after azole treatment of eumycetoma range from $40 \%$ with itraconazole to $70 \%$ with ketoconazole ${ }^{41}$. Several small studies have reported successful outcome following treatment with itraconazole monotherapy ${ }^{11,19,41}$, combination therapy with itraconazole plus surgery ${ }^{46}$ or ketoconazole plus surgery ${ }^{27}$, and combined itraconazole/flucytosine therapy $^{8}$. Voriconazole, a newer azole antifungal, has demonstrated in vitro activity against a wide range of moulds, including $F$. pedrosoi (MIC $\leq 0.03-1 \mu \mathrm{g} / \mathrm{mL})^{26}$ and S. apiospermum (MIC 0.03-0.5 $\left.\mu \mathrm{g} / \mathrm{mL}\right)^{26,33,44,48}$. Currently, there are no reports regarding the efficacy of voriconazole against eumycetoma due to Madurella spp.; however, voriconazole therapy has been used successfully to treat subcutaneous $S$. apiospermum infection in two patients ${ }^{12,25}$.

The fungal pathogens that cause chromoblastomycosis also are typically resistant to conventional pharmacologic therapies. DE BEDOUT et al..$^{15}$ reported that $67 \%$ of $F$. pedrosoi isolates are resistant to fluconazole (MIC $\geq 20 \mu \mathrm{g} / \mathrm{mL}$ ), $58 \%$ are resistant to flucytosine (MIC $\geq 25 \mu \mathrm{g} / \mathrm{mL}$ ), and $33 \%$ are resistant to amphotericin (MIC $\geq 4$ $\mu \mathrm{g} / \mathrm{mL})^{15}$. F. pedrosoi also has demonstrated resistance to itraconazole $\mathrm{e}^{4,37}$. Considerable variability has been observed among conventional antifungal therapies regarding clinical efficacy in the treatment of chromoblastomycosis. In a retrospective review of 51 cases in Mexico, BONIFAZ et al. reported that conventional therapies (cryosurgery, itraconazole, topical heat, amphotericin B, 5-flucytosine, ketoconazole, and calciferol) resulted in clinical cure in only $31 \%$ (16/ 51) of patients with chromoblastomycoses ${ }^{9}$. Ketoconazole is associated with only modest $(32 \%)$ improvement in chromoblastomycosis of slight-to-moderate severity and generally is considered ineffective in extensive diseas $\mathrm{e}^{41}$. Itraconazole monotherapy has demonstrated clinical effectiveness in patients with infection caused by $C$. carrionii or $F$. pedrosoi $^{8,11,29,40,42}$; however, its efficacy appears to be inversely associated with disease severity ${ }^{40,42}$. Concomitant cryotherapy has been associated with improved outcomes ${ }^{9,10,28}$, as has the addition of flucytosine ${ }^{8}$ or terbinafine (combination or alternate-week therapy) ${ }^{22}$ in more extensive cases caused by $F$. pedrosoi. Saperconazole demonstrates superior in vitro and in vivo activity against $F$. pedrosoi in mice compared with itraconazole and ketoconazole ${ }^{13}$, but its clinical effect remains to be evaluated.

Other therapies have been examined for potential effectiveness. Although 5-flucytosine has been associated with clinical success in small numbers of patients, this drug is not uniformly available in endemic areas $^{39}$, and resistance commonly develops during prolonged courses of therapy ${ }^{41,54}$. Thiabendazole, a commonly used antihelmintic, is effective in less than $50 \%{ }^{41}$ of patients, but its use is limited by gastrointestinal toxicities, especially at doses greater than $2 \mathrm{~g}$ daily ${ }^{5,41}$. A few case reports describe the clinical efficacy of terbinafine used alone ${ }^{17,47}$ or in combination with heat therapy ${ }^{50}$. ESTERRE et al. reported mycologic cure of chromoblastomycosis in $85.2 \%(23 / 27)$ of patients after 12 months of terbinafine therapy ${ }^{18}$. In this pilot study, the efficacy of terbinafine extended to patients with imidazole-refractory or chronic disease ${ }^{18}$.

Posaconazole is a new, potent, extended-spectrum, antifungal agent. It has demonstrated in vitro activity against many of the fungal pathogens that cause eumycetoma and chromoblastomy$\operatorname{cosis}^{14,16,20,33,38,49,52}$. Previously published case reports describe the efficacy of posaconazole in treating life-threatening infections caused by Acremonium strictum $^{24}, S$. apiospermum ${ }^{34}$, and Rhizopus spp. ${ }^{51}$ that persisted despite itraconazole or amphotericin B therapy. Importantly, posaconazole appears to penetrate bone. Posaconazole was used to successfully treat disseminated phaeohyphomycosis due to Exophiala spinifera with bone involvement in a 41-year-old woman with no known immunosuppression ${ }^{38}$ and multidrug resistant disseminated aspergillosis with bone involvement in a 64-year-old recipient of a lung transplant ${ }^{31}$. A subanalysis of patients from the present study who had aspergillosis refractory to or intolerant of conventional antifungal therapy showed that posaconazole resulted in significantly more successful outcomes (42\% vs $26 \% ; p<0.006)$ and demonstrated a survival benefit compared with an external control group ${ }^{55}$. Collectively, these observations support posaconazole's extended spectrum of antifungal activity and suggest that this triazole will have broad clinical usefulness in the treatment of invasive fungal infections.

Posaconazole appears to be safe and well-tolerated when administered long term. Headache and gastrointestinal disorders (nausea, diarrhea, vomiting, abdominal pain) are the most commonly reported treatment-emergent, treatment-related adverse events ${ }^{21,45}$. To date, posaconazole has not been associated with QTc prolongation nor negative inotropic effects and posaconazole does not cause visual disturbances. No major adverse events were described in case reports of chronic posaconazole administration ${ }^{3,30,34,38,51}$, even when administered continuously for longer than 20 months $^{3}$. Posaconazole inhibits activity of the hepatic enzyme cytochrome P450 (CYP) 3A4 but has no effect on CYP1A2, CYP2C8/9, CYP2D6, or CYP2E1 activity $^{56}$, and it is not a substrate of the CYP450 enzyme system.

\section{CONCLUSION}

Posaconazole therapy led to successful outcome in 10 of 12 patients with eumycetoma or chromoblastomycosis who had disease refractory 
to standard therapies. Clinical improvement observed in these patients is noteworthy considering all had a long history of chronic disease, with most having failed multiple prior therapies. Long-term posaconazole therapy ( $>2$ y) was well tolerated; none of the patients discussed above withdrew from the study because of adverse events. Furthermore, these findings support the use of posaconazole as a treatment option for patients with eumycetoma or chromoblastomycosis.

\section{RESUMO}

\section{Tratamento com posaconazol de casos de cromoblastomicose e micetoma maduromicótico resistentes a outros antifúngicos}

Eumicetoma e cromoblastomicose são infecções fúngicas crônicas do tecido subcutâneo que evoluem com aspecto desfigurado, raramente involuindo espontaneamente. A maioria dos pacientes não apresenta melhora sustentada por longo tempo com os tratamentos disponíveis, sendo de grande importância as novas opções terapêuticas. A eficácia do posaconazol, um novo agente antifúngico de amplo espectro do grupo dos triazóis, foi estudada em 12 pacientes com eumicetoma ou cromoblastomicose refratária às terapêuticas antifúngicas disponíveis.

Os pacientes receberam por no máximo 34 meses, doses divididas de $800 \mathrm{mg} /$ dia de posaconazol. Resposta clínica parcial ou completa foi considerada como sucesso; doença estável ou falha terapêutica foi considerada como insucesso.

Todos os 12 pacientes tinham infecções comprovadas ou prováveis, refratárias à terapêutica padrão preconizada. Sucesso clínico foi registrado em cinco de seis pacientes com eumicetoma e cinco de seis pacientes com cromoblastomicose. Em dois pacientes observou-se doença estável. Como parte do protocolo de extensão do tratamento, dois pacientes com eumicetoma que inicialmente tinham tido sucesso terapêutico e que após um intervalo maior de 10 meses apresentaram recidiva da micose, foram retratados com sucesso com posaconazol. Posaconazol foi bem tolerado durante o longo período de administração (até 1015 dias).

A terapêutica com posaconazol foi seguida de sucesso na maioria dos pacientes com eumicetoma ou cromoblastomicose refratária à terapêutica padrão, sugerindo que tal droga possa ser uma importante opção no tratamento de tais doenças.

\section{REFERENCES}

1. AHMED, A.; ADELMANN, D.; FAHAL, A. et al. - Environmental occurrence of Madurella mycetomatis, the major agent of human eumycetoma in Sudan. J. clin. Microbiol., 40: 1031-1036, 2002.

2. AHMED, A.O.; VAN LEEUWEN, W.; FAHAL, A. et al. - Mycetoma caused by Madurella mycetomatis: a neglected infectious burden. Lancet infect. Dis., 4: 566-574, 2004.

3. AL-ABDELY, H.; ALKHUNAIZI, A.; AL-TAWFIQ, J. et al. - Successful therapy of cerebral phaeohyphomycosis due to Ramichloridium mackenziei with new triazole, posaconazole. Med. Mycol., 43: 91-95, 2005.

4. ANDRADE, T.S.; CASTRO, L.G.M.; NUNES, R.S. et al. - Susceptibility of sequential Fonsecaea pedrosoi isolates from chromoblastomycosis patients to antifungal agents. Mycoses, 47: 216-221, 2004.
5. ARENAS, R. - Chromoblastomycosis: In: JACOBS, P. \& NALL, L, ed. Antifungal drug therapy. A complete guide for the practitioner. New York, Marcel Dekker, 1990. p. 43-51.

6. ASCIOGLU, S.; REX, J.H.; DE PAUW, B. et al. - Defining opportunistic invasive fungal infections in immunocompromised patients with cancer and hematopoietic stem cell transplants: an international consensus. Clin. infect. Dis., 34: 7-14, 2002.

7. BANSAL, A.S. \& PRABHAKAR, P. - Chromomycosis: a twenty-year analysis of histologically confirmed cases in Jamaica. Trop. geogr. Med., 41: 222-226, 1989.

8. BAYLES, M.A. - Tropical mycoses. Chemotherapy, 38(suppl. 1): 27-34, 1992.

9. BONIFAZ, A.; CARRASCO-GERARD, E. \& SAUL, A. - Chromoblastomycosis: clinical and mycologic experience of 51 cases. Mycoses, 44: 1-7, 2001.

10. BONIFAZ, A.; MARTINEZ-SOTO, E.; CARRASCO-GERARD, E. \& PENICHE, J. Treatment of chromoblastomycosis with itraconazole, cryosurgery, and a combination of both. Int. J. Derm., 36: 542-547, 1997.

11. BORELLI, D. - A clinical trial of itraconazole in the treatment of deep mycoses and leishmaniasis. Rev. infect. Dis., 9(suppl. 1): S57-S63, 1987.

12. BOSMA, F.; VOSS, A.; VAN HAMERSVELT, H.W. et al. - Two cases of subcutaneous Scedosporium apiospermum infection treated with voriconazole. Clin. Microbiol. Infect., 9: 750-753, 2003.

13. CARDONA-CASTRO, N.; AGUDELO-FLOREZ, P. \& RESTREPO-MOLINA, R. Chromoblastomycosis murine model and in vitro test to evaluate the sensitivity of Fonsecaea pedrosoi to ketoconazole, itraconazole and saperconazole. Mem. Inst. Oswaldo Cruz, 91: 779-784, 1996.

14. CARRILLO, A.J. \& GUARRO, J. - In vitro activities of four novel triazoles against Scedosporium spp. Antimicrob. Agents Chemother., 45: 2151-2153, 2001

15. DE BEDOUT, C.; GOMEZ, B.L. \& RESTREPO, A. - "In vitro" susceptibility testing of Fonsecaea pedrosoi to antifungals. Rev. Inst. Med. trop. S. Paulo, 39: 145-148, 1997.

16. ESPINEL-INGROFF, A. - Comparison of "in vitro" activities of the new triazole SCH56592 and the echinocandins MK-0991 (L-743,872) and LY303366 against opportunistic filamentous and dimorphic fungi and yeasts. J. clin. Microbiol., 36 2950-2956, 1998.

17. ESTERRE, P.; ANDRIANTSIMAHAVANDY, A.; RAMARCEL, E.R. \& PECARRERE, J.L. - Forty years of chromoblastomycosis in Madagascar: a review. Amer. J. trop. Med. Hyg., 55: 45-47, 1996.

18. ESTERRE, P.; INZAN, C.K.; RAMARCEL, E.R. et al. - Treatment of chromomycosis with terbinafine: preliminary results of an open pilot study. Brit. J. Derm., 134(suppl. 46): 33-36, 1996

19. FLETCHER, C.L.; MOORE, M.K. \& HAY, R.J. - Eumycetoma due to Madurella mycetomatis acquired in Jamaica. Brit. J. Derm. 145: 1018-1021, 2001.

20. GONZALEZ, G.M.; TIJERINA, R.; NAJVAR, L.K. et al. - Activity of posaconazole against Pseudallescheria boydii: "in vitro" and "in vivo" assays. Antimicrob. Agents Chemother., 47: 1436-1438, 2003.

21. GRAYBILL, J.R.; RAAD, I.; NEGRONI, R.; CORCORAN, G. \& PEDICONE, L. Posaconazole (POS) long-term safety in subjects with invasive fungal infections (IFIs). In: ANNUAL INTERSCIENCE CONFERENCE ON ANTIMICROBIAL AGENTS AND THERAPY (ICAAC), 44., Washington, DC, 2004. p. 415.

22. GUPTA, A.K.; TABORDA, P.R. \& SANZOVO, A.D. - Alternate week and combination itraconazole and terbinafine therapy for chromoblastomycosis caused by Fonsecaea pedrosoi in Brazil. Med. Mycol., 40: 529-534, 2002.

23. HAY, R.J.; MAHGOUB, E.S.; LEON, G.; AL SOGAIR, S. \& WELSH, O. - Mycetoma J. med. vet. Mycol., 30(suppl. 1): 41-49, 1992 


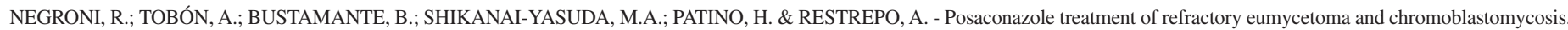
Rev. Inst. Med. trop. S. Paulo, 47(6):339-346, 2005.

24. HERBRECHT, R.; LETSCHER-BRU, V.; FOHRER, C. et al. - Acremonium strictum pulmonary infection in a leukemic patient successfully treated with posaconazole after failure of amphotericin B. Europ. J. clin. Microbiol. infect. Dis., 21: 814-817, 2002.

25. JEU, L.; PIACENTI, F.J.; LYAKHOVETSKIY, A.G. \& FUNG, H.B. - Voriconazole. Clin. Therap., 25: 1321-1381, 2003.

26. JOHNSON, E.M.; SZEKELY, A. \& WARNOCK, D.W. - "In-vitro" activity of voriconazole, itraconazole and amphotericin B against filamentous fungi. J. Antimicrob. Chemother., 42: 741-745, 1998

27. KHATRI, M.L.; AL HALALI, H.M.; FOUAD KHALID, M.; SAIF, S.A. \& VYAS, M.C. - Mycetoma in Yemen: clinicoepidemiologic and histopathologic study. Int. J. Derm., 41: 586-593, 2002.

28. KULLAVANIJAYA, P. \& ROJANAVANICH, V. - Successful treatment of chromoblastomycosis due to Fonsecaea pedrosoi by the combination of itraconazole and cryotherapy. Int. J. Derm., 34: 804-807, 1995.

29. LAVALLE, P.; SUCHIL, P.; DE OVANDO, F. \& REYNOSO, S. - Itraconazole for deep mycoses: preliminary experience in Mexico. Rev. infect. dis., 9(suppl. 1): S64-S70, 1987.

30. LEWIS, J.S.; ANSTEAD, G. \& GRAYBILL, J. - Successful treatment of disseminated coccidioidomycosis (Coccidioides immitis) with posaconazole, a new triazole ( $\mathrm{SCH}$ 56592): a case report. In: CONGRESS OF THE INTERNATIONAL SOCIETY FOR HUMAN AND ANIMAL MYCOLOGY, 15., San Antonio, Texas, 2003. Abstract. p. 256.

31. LODGE, B.A.; ASHLEY, E.D.; STEELE, M.P. \& PERFECT, J.R. - Aspergillus fumigatus empyema, arthritis, and calcaneal osteomyelitis in a lung transplant patient successfully treated with posaconazole. J. clin. Microbiol., 42: 1376-1378, 2004.

32. MAHGOUB, E.S. - Agents of mycetoma: In: MANDELL, G.L.; BENNETT, J.E. \& DOLIN, R., ed. Mandell, Douglas, and Bennett's principles and practices of infectious diseases. 5. ed. Philadelphia, Churchill Livingstone, 2000. p. 2702-2706.

33. MELETIADIS, J.; MEIS, J.F.; MOUTON, J.W. et al. - "In vitro" activities of new and conventional antifungal agents against clinical Scedosporium isolates. Antimicrob. Agents Chemother., 46: 62-68, 2002.

34. MELLINGHOFF, I.K. WINSTON, D.J.; MUKWAYA, G. \& SCHILLER, G.J. - Treatment of Scedosporium apiospermum brain abscesses with posaconazole. Clin. infect. Dis., 34: 1648-1650, 2002

35. MILAM, C.P. \& FENSKE, N.A. - Chromoblastomycosis. Derm. Clin., 7: 219-225, 1989.

36. MINOTTO, R.; BERNARDI, C.D.; MALLMANN, L.F.; EDELWEISS, M.I. \& SCROFERNEKER, M.L. - Chromoblastomycosis: a review of 100 cases in the state of Rio Grande do Sul, Brazil. J. Amer. Acad. Derm., 44: 585-592, 2001.

37. MORINO, G.; GIACCARDI, G.C.; BRUNDISINI, R.; ANSALONI, L. \& GIACCARDI, S. - A unique case of bladder mycetoma. Trop. Doctor, 32: 43-44, 2002.

38. NEGRONI, R. \& ARECHAVALA, A.I. - Itraconazole: pharmacokinetics and indications. Arch. med. Res., 24: 387-393, 1993.

39. NEGRONI, R.; HELOU, S.H.; PETRI, N. et al. - Case study: posaconazole treatment of disseminated phaeohyphomycosis due to Exophiala spinifera. Clin. infect. Dis., 38(3): e15-e20, 2004

40. QUEIROZ-TELLES, F.; McGINNIS, M.R.; SALKIN, I. \& GRAYBILL, J.R. Subcutaneous mycoses. Infect. Dis. Clin. N. Amer., 17: 59-85, 2003.

41. QUEIROZ-TELLES, F.; PURIM, K.S.; FILLUS, J.N. et al. - Itraconazole in the treatment of chromoblastomycosis due to Fonsecaea pedrosoi. Int. J. Derm., 31: 805-812, 1992.
42. RESTREPO, A. - Treatment of tropical mycoses. J. Amer. Acad. Derm., 31(3 pt. 2): S91-S102, 1994

43. RESTREPO, A.; GONZALEZ, A.; GOMEZ, I.; ARANGO, M. \& DE BEDOUT, C. Treatment of chromoblastomycosis with itraconazole. Ann. N. Y. Acad. Sci., 544: 504-516, 1988.

44. SABATELLI, F.J.; LOEBENBERG, D.; MENDRICK, C.A. et al. - In vitro activities of posaconazole, fluconazole, itraconazole, voriconazole, and amphotericin B against approximately 18,000 strains of clinically significant yeasts and moulds. In: ANNUAL INTERSCIENCE CONFERENCE ON ANTIMICROBIAL AGENTS AND CHEMOTHERAPY (ICAAC), 44., Washington, DC, 2004. p. 439.

45. SAFDAR, A.; PAPADOPOULOS, E.B. \& YOUNG, J.W. - Breakthrough Scedosporium apiospermum (Pseudallescheria boydii) brain abscess during therapy for invasive pulmonary aspergillosis following high-risk allogeneic hematopoietic stem cell transplantation: scedosporiasis and recent advances in antifungal therapy. Transplant. infect. Dis., 4: 212-217, 2002.

46. SANSONE, A.; COURTNEY, R.; BRUNDAGE, T. \& LAUGHLIN, M. - Safety and tolerability of posaconazole: evaluation of 18 controlled, healthy volunteer studies. In: ANNUAL INTERSCIENCE CONFERENCE ON ANTIMICROBIAL AGENTS AND CHEMOTHERAPY (ICAAC), 44., Washington, DC, 2004. p. 20-21.

47. SEVERO, L.C.; VETORATTO, G.; OLIVEIRA, F.M. \& LONDERO, A.T. - Eumycetoma by Madurella grisea: report of the first case observed in the southern Brazilian region. Rev. Inst. Med. trop. S. Paulo, 41: 139-142, 1999.

48. SEVIGNY, G.M. \& RAMOS-CARO, F.A. - Treatment of chromoblastomycosis due to Fonsecaea pedrosoi with low-dose terbinafine. Cutis, 66: 45-46, 2000.

49. SHAH, K.B.; WU, T.G.; WILHELMUS, K.R. \& JONES, D.B. - Activity of voriconazole against corneal isolates of Scedosporium apiospermum. Cornea, 22: 33-36, 2003.

50. SUTTON, D.A. - Laboratory evaluation of new antifungal agents against rare and refractory mycoses. Curr. Opin. infect. Dis., 15: 575-582, 2002.

51. TANUMA, H.; HIRAMATSU, M.; MUKAI, H. et al. - A case of chromoblastomycosis effectively treated with terbinafine. Characteristics of chromoblastomycosis in the Kitasato region, Japan. Mycoses, 43: 79-83, 2000

52. TOBÓN, A.M.; ARANGO, M.; FERNANDEZ, D. \& RESTREPO, A. - Mucormycosis (zygomycosis) in a heart-kidney transplant recipient: recovery after posaconazole therapy. Clin. infect. Dis., 36: 1488-1491, 2003.

53. UCHIDA, K.; YOKOTA, N. \& YAMAGUCHI, H. - "In vitro" antifungal activity of posaconazole against various pathogenic fungi. Int. J. Antimicrob. Agents, 18: 167 $172,2001$.

54. VERDOLINI, R.; AMERIO, P.; BUGATTI, L. et al. - Madura's foot: report of a case caused by Madurella mycetomatis. Europ. J. Derm., 10: 627-629, 2000.

55. WAGNER, K. - Agents of chromomycosis: In: MANDELL, G.L.; BENNETT, J.E. \& DOLIN, R., ed. Mandell, Douglas, and Bennett's principles and practices of infectious diseases. 5. ed. Philadelphia, Churchill Livingstone, 2000. p. 2699-2702.

56. WALSH, T.; PATTERSON, T.; LANGSTON, A. et al. - Posaconazole for treatment of invasive aspergillosis in patients who are refractory to or intolerant of conventional therapy: an externally controlled blinded trial [abstract]. Blood, 102: 195-196, 2003.

57. WEXLER, D.; COURTNEY, R.; RICHARDS, W. et al. - Effect of posaconazole on cytochrome p450 enzymes: a randomized, open-label, two-way crossover study. Europ. J. pharm. Sci., 21: 645-653, 2004

58. ZAAS, D. - Cases from the Osler Medical Service at Johns Hopkins University: Scedosporium apiospermum mycetoma of the lung. Amer. J. Med., 113: 760-762, 2002.

Received: 11 January 2005

Accepted: 15 August 2005 